\title{
SIMULASI PERUBAHAN PENGGUNAAN LAHAN TERHADAP KARAKTERISTIK HIDROLOGI DAERAH ALIRAN SUNGAI CILIMAN
}

\section{Simulation of Land Use Change on Hidrological Characteristics of the Ciliman Watershed}

\section{Leonard Kristofery1)*, Kukuh Murtilaksono2) dan Dwi Putro Tejo Baskoro2)}

\author{
1) Program Studi Ilmu Pengelolaan DAS Sekolah Pascasarjana IPB University, Kampus IPB Darmaga \\ 2) Departemen Ilmu Tanah dan Sumberdaya Lahan, Fakultas Pertanian IPB University, J1. Meranti Kampus IPB \\ Darmaga Bogor 16680
}

\begin{abstract}
The Ciliman watershed is one of the watersheds in Kabupeten Lebak and Kabupaten Pandeglang with a total area \pm $500 \mathrm{~km}^{2}$. According to report of Badan Nasional Penanggulangan Bencana (BNPB) Serang City, flooding often occurs in the Ciliman watershed because of the overflow of the Ciliman tributaries, this occurs because of the conversion of land use in the upstream area of Ciliman watershed so that during the rainy season, rainwater does not seep into the ground but directly into runoff. The aim of the research is to simulate several soil and water conservation as an effort to better manage the Ciliman watershed and determine the best land use scenario in accordance with the biophysical Ciliman watershed. This study applied SWAT model as a tool to simulate several soil and water conservation technical at Ciliman watershed. The scenarios simulated were: 0) existing condition, 1) application of forest area functions, 2) application of soil and water conservation techniques using RTK RHL, 3) application of regional spatial planning (RTRW). The results showed that scenario 2 (RTK $R H L)$ was the best scenario by overall. Scenario 2 can reduce the Qmax/Q min ratio by $31.63 \%$ compared to other scenarios. And also can reduce coefficient of runoff by $24 \%$ and direct runoff by $23.55 \%$ and increase baseflow by $16.20 \%$ and water yield by $1.77 \%$.
\end{abstract}

Keywords: runoff, soil conservation, watershed, water conservation

\begin{abstract}
ABSTRAK
Daerah Aliran Sungai (DAS) Ciliman merupakan salah satu DAS yang berada di Kabupaten Lebak dan Kabupaten Pandeglang dengan luas total DAS $\pm 500 \mathrm{~km}^{2}$. Banjir sering terjadi di DAS Ciliman akibat meluapnya anak-anak sungai Ciliman, karena konversi penggunaan lahan di daerah hulu Ciliman sehingga pada waktu musim penghujan, air hujan tidak meresap kedalam tanah tapi langsung menjadi air limpasan. Penerapan Konservasi Tanah dan Air (KTA) merupakan salah satu upaya untuk meningkatkan kualitas DAS Ciliman. Studi ini bertujuan untuk mensimulasikan beberapa teknik KTA sebagai upaya pengelolaan DAS Ciliman yang lebih baik dan menetapkan skenario penggunaan lahan yang terbaik sesuai dengan kondisi biofisik DAS Ciliman. Penelitian ini menggunakan model SWAT sebagai alat untuk mensimulasikan beberapa skenario teknik KTA di DAS Ciliman. Skenario yang disimulasikan adalah: 0) Penggunaan lahan existing, 1) Penerapan fungsi kawasan hutan, 2) Penerapan teknik Konservasi Tanah dan air menggunakan RTK RHL dari BPDAS Ciliwung-Citarum, 3) Penerapan Rencana Tata Ruang Wilayah. Hasil penelitian menunjukkan bahwa skenario 2 (RTK RHL) merupakan skenario terbaik dibandingkan dengan skenario yang lainnya. Skenario ini mampu menurunkan rasio Qmax/Qmin sebesar 31.63\% dibandingkan skenario yang lainnya. Skenario 2 juga dapat menurunkan koefisien aliran tahunan sebesar $24 \%$ dan aliran permukaan langsung (direct runoff) sebesar 23.55\% dan meningkatkan aliran bawah permukaan sebesar $16.20 \%$ serta water yield sebesar $1.77 \%$.
\end{abstract}

Kata kunci: aliran permukaan, konservasi tanah, DAS, konservasi air

\section{PENDAHULUAN}

Perubahan penggunaan lahan yang terjadi dengan cepat secara tidak langsung akan memberikan dampak pada daerah yang mengalami perubahan tersebut maupun daerah sekitarnya. Misalnya pengembangan pemukiman penduduk di daerah resapan hujan, akan mengakibatkan banjir pada daerah sekitar yang dulunya mengandalkan daerah resapan sebagai penahan air hujan. Fenomena alih fungsi lahan senantiasa terjadi dalam pemenuhan aktifitas sosial ekonomi yang menyertai pertumbuhan penduduk kota. Persediaan lahan yang bersifat tetap sedangkan permintaan yang terus meningkat menjadikan pengunaan lahan suatu kota berubah kearah aktivitas yang lebih menguntungkan dilihat dari potensi sekitarnya yang ada.

Perubahan penggunaan lahan dapat terjadi karena adanya pertambahan jumlah penduduk di daerah tersebut. Pertumbuhan penduduk menyebabkan perbandingan antara 
jumlah penduduk dengan lahan pertanian tidak seimbang (Asdak, 2010). Meningkatnya jumlah penduduk mengakibatkan meningkatnya kebutuhan akan pangan namun disisi lainnya luas lahan pertanian terus mengalami penurunan akibat terkonversi menjadi pemukiman. Menurut data Badan Pusat

Daerah Aliran Sungai (DAS) Ciliman merupakan salah satu DAS yang berada di Kabupaten Lebak dan Kabupaten Pandeglang. Luas total DAS Ciliman \pm 500 km2 mengalir sepanjang $55 \mathrm{~km}$ yang berhulu di Gunung Liman, Gunung Kencana dan Gunung Kendeng serta bermuara di teluk Lada. Menurut data Badan Nasional Penanggulangan Bencana (BNPB) Kota Serang, banjir sering terjadi di DAS Ciliman akibat meluapnya anak-anak sungai Ciliman, ini terjadi karena konversi penggunaan lahan di daerah hulu Ciliman sehingga pada waktu musim penghujan, air hujan tidak meresap kedalam tanah tapi langsung menjadi air limpasan. Bencana alam banjir dapat terjadi baik secara alami maupun diakibatkan oleh aktifitas manusia itu sendiri. Penebangan hutan di bagian hulu DAS berakibat fatal bagi kelangsungan ekosistem dan lingkungan hutan, sekaligus mengakibatkan bencana bagi daerah hilirnya. Konservasi lahan di DAS Ciliman terjadi karena lahan tersebut digunakan masyarakat di DAS Ciliman untuk bertani dan berkebun yang aktifitas tersebut tidak sesuai dengan kaidah konservasi tanah dan air.

Pendekatan analisis karakteristik hidrologi DAS merupakan salah satu landasan teori yang sangat baik dalam mengintegrasikan informasi komponen-komponen suatu sistem DAS menjadi model Hidrologi DAS. Penggunaan model SWAT dapat mengidentifikasi, menilai, mengevaluasi tingkat permasalahan suatu DAS, khususnya pada DAS Ciliman dan berbagai alat untuk memilih tindakan pengelolaan dalam mengendalikan permasalahan tersebut. Dengan demikian diharapkan dengan penggunaan model SWAT ini dapat dikembangkan beberapa skenario untuk menentukan kondisi perencanaan pengelolaan DAS Ciliman.

Tujuan dari penelitian ini adalah: i) Mensimulasikan beberapa teknik KTA sebagai upaya pengelolaan DAS Ciliman yang lebih baik, ii) Menetapkan skenario penggunaan lahan yang terbaik sesuai dengan kondisi biofisik DAS Ciliman.

\section{BAHAN DAN METODE}

\section{Tempat dan Waktu Penelitian}

Waktu persiapan penelitian dimulai bulan Januari 2017 dan analisis laboratorium dilakukan di Departemen Ilmu Tanah dan Sumberdaya Lahan, Kampus IPB Dramaga. Lokasi penelitian terletak di DAS Ciliman (titik outlet Munjul) yang masuk dalam wilayah Kabupaten Pandeglang (BPS, 2015a) dan Kabupaten Lebak (BPS, 2015b), Provinsi Banten.

\section{Alat dan Bahan}

Alat yang digunakan dalam penelitian adalah seperangkat komputer, Software ArcGIS 10.1, Arc SWAT versi 10.1.18, Microsoft Office 2010, global positioning system (GPS), ring sampler, double ring infiltrometer dan alat-alat lainnya yang diperlukan untuk pengambilan sample fisik tanah dan analisis di laboratorium. Adapun bahan yang digunakan dalam penelitian terdiri dari: 1) Peta DEM (Digital Elevation Model) Banten dari citra SRTM resolusi $30 \mathrm{~m}, 2)$ Peta penggunaan lahan DAS Ciliman skala 1: 250,000, 3) Peta Tanah DAS Ciliman skala 1: 250,000 , 4) Data iklim harian (curah hujan, suhu, kelembaban udara, kecepatan angin dan radiasi matahari) tahun 2009-2015, 5) Data debit observasi harian Sungai Ciliman tahun 2009-2015, 6) Data karakteristik fisik tanah DAS Ciliman (pengamatan lapang).

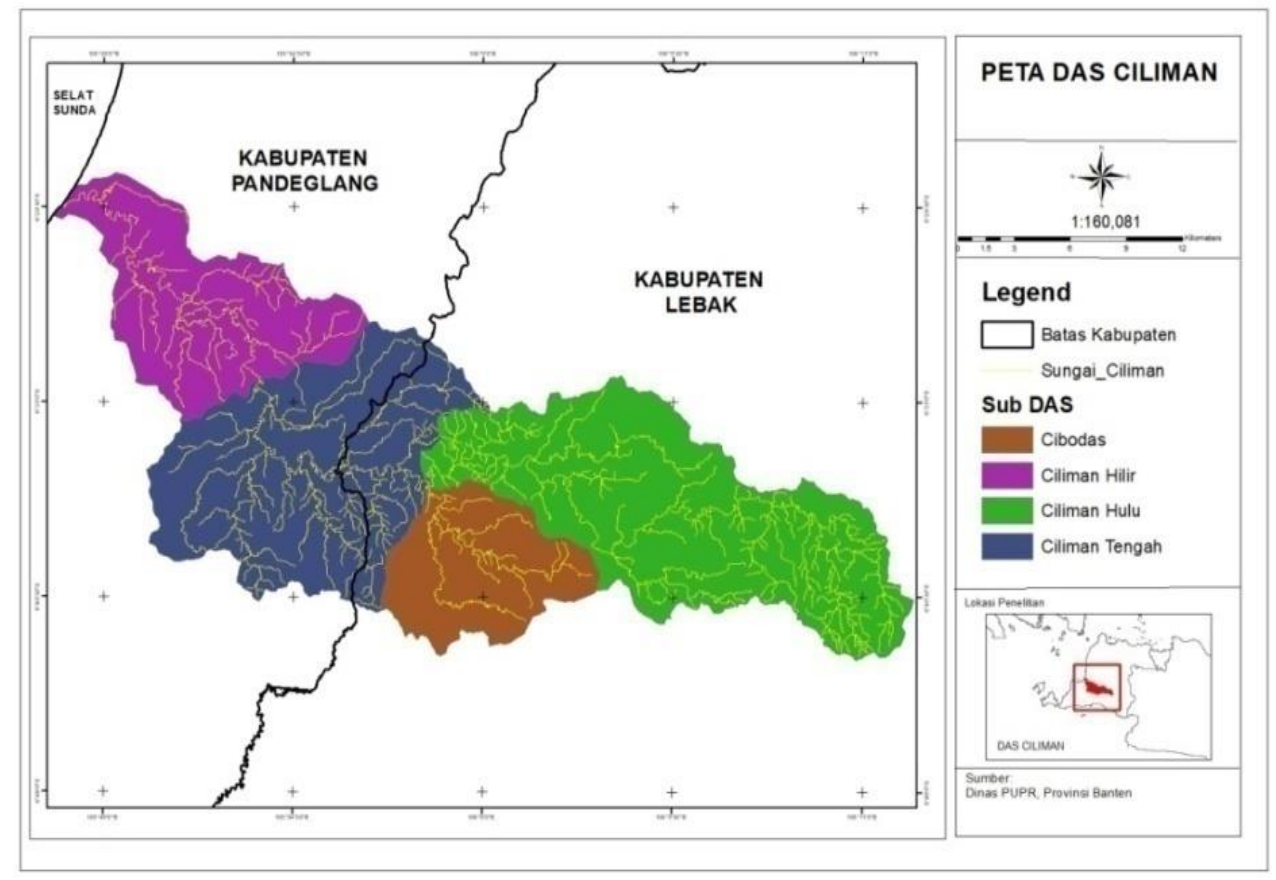

Gambar 1. Lokasi penelitian (DAS Ciliman). 


\section{Prosedur Penelitian}

Penelitian ini menggunakan model hidrologi Soil and Water Assessment Tool (SWAT). Penelitian terdiri dari tiga tahapan, yaitu: tahapan pengumpulan data, tahapan mensimulasikan beberapa teknik KTA sebagai upaya pengelolaan DAS Ciliman yang lebih baik dan tahapan menetapkan skenario penggunaan lahan yang terbaik sesuai dengan kondisi biofisik DAS Ciliman.

\section{Pengumpulan Data}

Pengumpulan data berupa data primer dan sekunder disesuaikan dengan masukan data (input) yang diperlukan pada model SWAT. Pengumpulan data sekunder dilakukan dibeberapa tempat diantaranya adalah Balai Pengelolaan Daerah Aliran Sungai (BPDAS) Ciliwung-Citarum, Balai Pengelolaan Sumber Daya Air (BPSDA) Ciliman-Cisawarna, Dinas Pekerjaan Umum dan Penataan Ruang (PUPR) Provinsi Banten dan Badan Meteorologi, Klimatologi, Badan Planologi Kehutanan (BAPLAN) Kementerian Lingkungan Hidup dan Kehutanan dan Geofisika (BMKG) Provinsi Banten.

\section{Mensimulasikan beberapa teknik KTA sebagai upaya pengelolaan DAS Ciliman yang lebih baik}

Skenario penggunaan lahan ini dilakukan dengan analisis model Soil and Water Assesment Tool (SWAT). Skenario penggunaan lahan yang digunakan pada penelitian ini adalah sebagai berikut:

- Skenario 0: penggunaan lahan existing.

- Skenario 1: penerapan fungsi kawasan hutan. Skenario ini merujuk pada Surat Keputusan Menteri Kehutanan Nomor: P.50/Menhut-II/2009 tentang Penegasan Status dan Fungsi Kawasan Hutan

- Skenario 2: penerapan teknik konservasi tanah dan air. Skenario ini menggunakan peta RTK RHL dari BPDAS Ciliwung-Citrum yang dioverlay dengan peta penggunaan lahan tahun 2015.

- Skenario 3: Penerapan Rencana Tata Ruang Wilayah (RTRW). skenario ini merujuk pada RTRW Kabupaten Lebak tahun 2014-2034 dan RTRW Kabupaten Pandeglang tahun 2011-2031 (Pemprov Banten, 2011)

\section{Menetapkan skenario penggunaan lahan yang terbaik sesuai dengan kondisi biofisik DAS Ciliman}

Arahan pengelolaan DAS didasarkan pada skenario yang paling baik dalam meningkatkan kualitas DAS. Skenario KTA terbaik yang dipilih untuk direkomendasikan untuk pengelolaan DAS adalah berdasarkan kriteria kemampuannya dalam menurunkan koefisien regim aliran (KRA) dan koefisien aliran tahunan (KAT).

a. Koefisien Regim Aliran (KRA)

$$
K R A=\frac{Q \max }{Q \min }
$$

Menurut Dirjen RLPS dalam Permenhut No.61 tahun 2014 bahwa kriteria kualitas DAS berdasarkan KRA ditunjukkan pada Tabel 1.

Tabel 1. Kriteria kualitas DAS berdasarkan nilai KRA

\begin{tabular}{lcc}
\hline & Kategori & KRA \\
\hline Sangat Rendah & $\leq 20$ \\
Rendah & $20-50$ \\
Sedang & $50-80$ \\
Tinggi & $80-110$ \\
Sangat Tinggi & $>110$ \\
\hline Sum:
\end{tabular}

Sumber: Kemenhut, 2014

b. Koefisien Aliran Tahunan (KAT)

$$
K A T=\frac{\text { Direct Runoff }(\mathrm{mm})}{\text { Curah Hujan }(\mathrm{mm})}
$$

Menurut Dirjen RLPS dalam Permenhut No. 61 tahun 2014 bahwa kriteria kualitas DAS berdasarkan KAT ditunjukkan pada Tabel 2.

Tabel 2. Kriteria kualitas DAS berdasarkan nilai KAT

\begin{tabular}{lcc}
\hline & Kategori & KAT \\
\hline Sangat Rendah & $\leq 0,2$ \\
Rendah & $0,2-0,3$ \\
Sedang & $0,3-0,4$ \\
Tinggi & $0,4-0,5$ \\
Sangat Tinggi & $>0,5$ \\
\hline
\end{tabular}

Sumber: Kemenhut, 2014

\section{HASIL DAN PEMBAHASAN}

\section{Hasil (Output) Simulasi Model SWAT}

Hasil delineasi model SWAT dengan ambang batas (threshold) 500 ha, didapatkan 23 sub-das yang terdelineasi oleh model dengan titik outlet berada di outlet Munjul (sub basin 3). Luasan DAS yang terdelineasi secara keseluruhan sebesar 3,4549.61 ha, dimana luasan terbesar berada di Sub Basin 17 dengan luasan sebesar 4,639.91 ha (sekitar $13.43 \%$ dari luas DAS), sementara luasan terkecil berada di Sub Basin 13 dengan luasan sebesar 217.51 ha (sekitar $0.66 \%$ dari luas DAS).

Hydrology Response Unit (HRU) merupakan unit satuan hidrologi yang terdiri dari penggunaan lahan, jenis tanah dan lereng. Analisis HRU dalam model SWAT menggunakan threshold $0 \%$ baik untuk penggunaan lahan, tanah dan lereng, dengan kata lain tidak ada batasan penggunaan lahan, jenis tanah dan lereng yang diabaikan oleh model. Hasil HRU yang terbentuk dalam model SWAT sebanyak 1,058 HRU.

\section{Kalibrasi dan Validasi Model SWAT}

Hasil kalibrasi model SWAT didapatkan bahwa nilai $\mathrm{R}^{2}$ dan NSE masing-masing adalah 0.77 dan 0.67. Berdasarkan kategori tingkat performa model menurut Moriasi et al. (2007) model tersebut dapat dikatakan memuaskan karena >0.5 (Gambar 2). Sementara untuk validasi yang dilakukan pada tahun 2015 menghasilkan $\mathrm{R}^{2}$ dan NSE masing-masing adalah 0.77 dan 0.63 dikategorikan memuaskan (Gambar 3). 


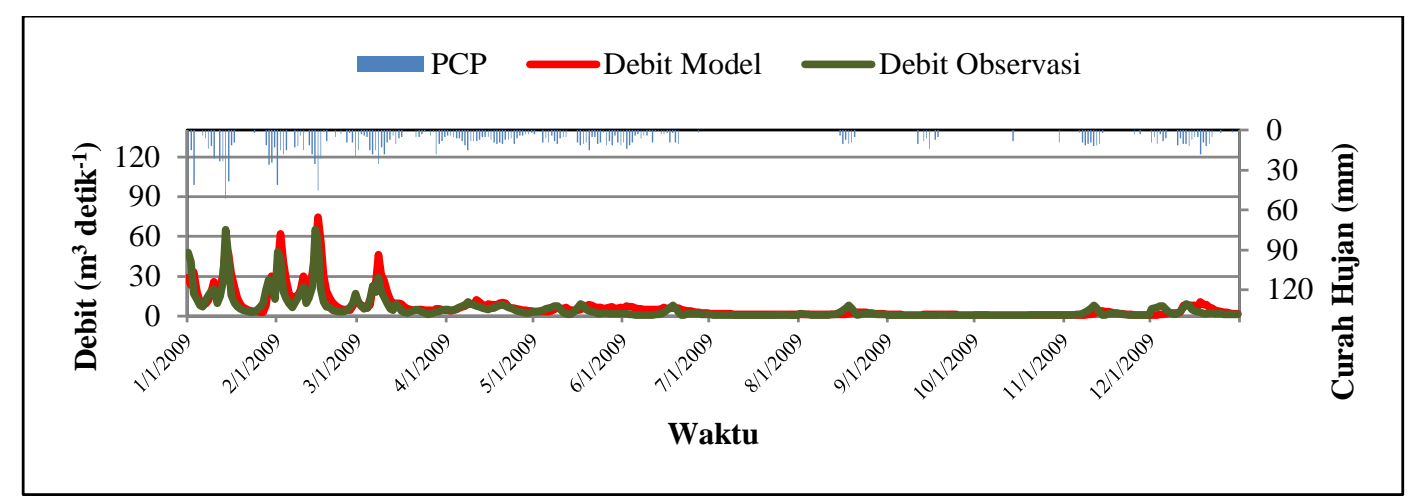

Gambar 2. Hasil kalibrasi model SWAT DAS Ciliman (tahun 2009)

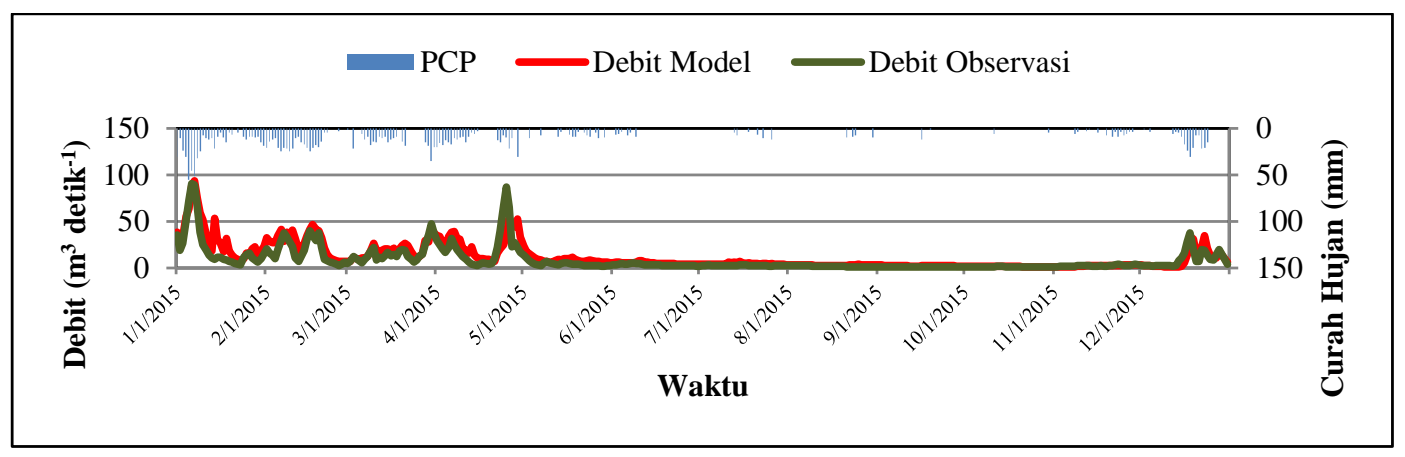

Gambar 3. Hasil validasi model SWAT DAS Ciliman (tahun 2015)

Setelah dilakukan kalibrasi dan validasi pada model dan model dinyatakan memuaskan. Dengan demikian, model dapat digunakan untuk simulasi skenario untuk menghasilkan arahan pengelolaan suatu DAS.

\section{Karakteristik Hidrologi DAS Ciliman Berdasarkan Model SWAT}

Model SWAT menunjukan bahwa curah hujan yang jatuh pada Wilayah DAS Ciliman (tahun 2015) sebesar 2,156.13 mm. Dari total curah hujan yang jatuh, menghasilkan air (water yield) sebesar 1,120.26 mm $(51.95 \%)$. Hasil air tersebut berasal dari aliran permukaan sebesar $414.39 \mathrm{~mm}$, aliran lateral $398.14 \mathrm{~mm}$, dan aliran dasar sebesar $271.87 \mathrm{~mm}$ (Tabel 3). Total curah hujan yang menjadi aliran permukaan langsung (direct runoff) $540.67 \mathrm{~mm}$ dengan Koefisien Aliran Tahunan (KAT) sebesar 0.25 dapat dikatakan bahwa kemampuan DAS Ciliman dalam meresapkan air hujan ke dalam tanah masih baik karena nilai koefisien aliran permukan yang masih dikatakan rendah yakni $>0.3$.

Tabel 3. Karakteristik hidrologi DAS Ciliman hasil simulasi model SWAT tahun 2015

\begin{tabular}{clr}
\hline No & Karakteristik Hidrologi & Nilai \\
\hline 1 & Curah Hujan (mm) & $2,156.13$ \\
2 & Aliran Permukaan (mm) & 414.39 \\
3 & Aliran Lateral (mm) & 398.14 \\
4 & Aliran Dasar (mm) & 271.87 \\
5 & Water Yield (mm) & $1,120.26$ \\
6 & DRO & 540.67 \\
7 & KAT & 0.25 \\
8 & KRA & 96.63 \\
\hline
\end{tabular}

Berdasarkan fluktuasi debitnya, rata-rata debit yang terjadi pada tahun 2015 sebesar $11.88 \mathrm{~m}^{3}$ detik $^{-1}$, dengan rata-rata debit tertinggi terjadi pada Bulan Januari yaitu sebesar $100.50 \mathrm{~m}^{3}$ detik $^{-1}$. Sementara untuk rata-rata debit terendah terjadi pada Bulan November yaitu sebesar $1.03 \mathrm{~m}^{3}$ detik $^{-1}$. Kemudian berdasarkan nilai Koefisien Rejim Aliran (KRA) yang menggambarkan rasio Qmax (debit maskimum) dan Qmin (debit minimum) sebagai respon curah hujan yang masuk kedalam suatu outlet DAS menunjukan bahwa KRA yang terjadi pada tahun 2015 cukup tinggi yaitu sebesar 98.63 (klasifikasi DAS tergolong buruk) (Tabel 4).

Tabel 4. Fluktuasi debit $\left(\mathrm{m}^{3} \operatorname{detik}^{-1}\right)$ DAS Ciliman hasil simulasi model SWAT tahun 2015

\begin{tabular}{clr}
\hline No & Karakteristik Hidrologi & \multicolumn{1}{c}{ Nilai } \\
\hline 1 & Qrata-rata $\left(\mathrm{m}^{3}\right.$ detik $\left.^{-1}\right)$ & 11.88 \\
2 & Qmax $\left(\mathrm{m}^{3}\right.$ detik $\left.^{-1}\right)$ & 100.50 \\
3 & Qmin $\left(\mathrm{m}^{3}\right.$ detik $\left.^{-1}\right)$ & 1.03 \\
4 & KRA & 98.63 \\
\hline
\end{tabular}

*Qmax: Debit maksimum, Qmin: Debit minimum, Qrata-rata: Debit rata-rata

Nilai KRA yang tinggi menunjukkan bahwa kisaran nilai limpasan pada musim penghujan (air banjir) yang terjadi besar, sedang pada musim kemarau aliran air yang terjadi sangat kecil atau menunjukkan kekeringan. Secara tidak langsung kondisi ini menunjukkan bahwa daya resap lahan di DAS kurang mampu menahan dan menyimpan air hujan yang jatuh dan air limpasannya banyak yang terus masuk ke sungai dan terbuang ke laut sehingga ketersediaan air di DAS saat musim kemarau sedikit (Dirjen RLPS, 2014). 


\section{Simulasi Teknik Konservasi Tanah dan Air dengan Model SWAT}

Hasil simulasi skenario KTA menggunakan model SWAT menunjukan bahwa penerapan teknik KTA mampu menurunkan KAT dan KRA dapat dilihat dari nilai KRA pada masing-masing skenario mengalami penurunan dari kondisi eksisting (Skenario 0). Penurunan KRA tertinggi ada pada skenario 2 sebesar $31.63 \%$ (menurun dari 98.63 pada kondisi eksisting menjadi 67.43) sehingga kualitas DAS digolongkan sedang. Sementara penurunan KAT tertinggi ada pada kenario 2 sebesar $24 \%$ (menurun dari 0.25 pada kondisi eksisting menjadi 0.19) sehingga kualitas DAS digolongkan sangat baik (Tabel 5).

\section{Arahan Pengelolaan DAS Ciliman}

Berdasarkan hasil simulasi SWAT di DAS Ciliman diketahui bahwa pengelolaan DAS dengan penerapan teknik Konservasi Tanah dan Air dengan mengacu pada RTK RHL DAS Ciliman dapat menurunkan aliran permukaan, aliran lateral, DRO dan KAT sehingga dapat meningkatkan kualitas DAS. Sehingga skenario 2 dianggap merupakan skenario terbaik dalam pengelolaan DAS Ciliman. Luas penerapan skenario 2 adalah 14,193.28 ha dengan rekomendasi terluas adalah penerapan penghijauan di kawasan budidaya-kawasan budidaya DAS tengah (PB-TKB) dengan luas 11,593.10 ha.

Skenario 2 mampu menekan aliran permukaan lebih besar dibandingkan skenario yang lain sehingga meningkatkan aliran dasar sebesar dari kondisi eksisting (Gambar 4). Disamping meningkatkan aliran dasar, skenario 2 juga lebih efektif dalam menurunkan koefisien aliran tahunan dari 0.25 (kondisi eksisting) menjadi 0.19 lebih rendah dibandingkan dengan skenario yang lainnya (Gambar 5).

Penerapan pola agroforestri di tegalan menunjukkan bahwa adanya komponen penyusun tanaman kayu (pohon) pada sistem agroforestri akan memperbaiki karakteristik tanah baik sifat fisika, kimia maupun biologi tanah. Perakaran pohon akan memperbaiki sifat fisika tanah terutama struktur dan porositas tanah. Keberadaan pohon juga akan memperbaiki sifat kimia tanah dengan menambah kandungan bahan organik tanah. Penerapan pola agroforestri akan memperbaiki infiltrasi dan perkolasi tanah, sehingga meningkatkan aliran dasar (Junaidy, 2013).

Luas penerapan skenario 2 adalah $14,193.28$ ha dengan rekomendasi terluas adalah penerapan penghijauan di kawasan budidaya-kawasan budidaya DAS tengah (PBTKB) dengan luas 11,593.10 ha. Penerapan skenario 2 secara rinci dapat dilihat pada Tabel 6. Rekomendasi pada skenario 2 adalah PB-HKB (Penghijauan di Kawasan Budidaya-Kawasan Bidudaya DAS Hulu), PB-LKB (Penghijauan di Kawasan Budidaya-Kawasan Budidaya DAS Hilir), PB-TKB (Penghijauan di Kawasan BudidayaKawasan Budidaya DAS Tengah), RL-THL (Reboisasi pada Hutan Lindung-Hutan Lindung di DAS Tengah), RPHHP (Reboisasi pada Hutan Produksi-Hutan Produksi DAS Hulu), RP-THP (Reboisasi pada Hutan ProduksiHutan Produksi DAS Tengah).

Tabel 5. Hasil simulasi karakteristik hidrologi model SWAT masing-masing skenario tahun 2015.

\begin{tabular}{|c|c|c|c|c|c|}
\hline No & Karakteristik Hidrologi & Skenario 0 & Skenario 1 & Skenario 2 & Skenario 3 \\
\hline 1 & Curah Hujan (mm) & $2,156.13$ & $2,156.13$ & $2,156.13$ & $2,156.13$ \\
\hline 2 & Aliran Permukaan (mm) & 410.48 & 407.75 & 404.45 & 406.31 \\
\hline 3 & Aliran Lateral (mm) & 398.14 & 384.00 & 330.33 & 363.55 \\
\hline 4 & Aliran Dasar (mm) & 271.87 & 290.55 & 324.44 & 294.52 \\
\hline 5 & Water Yield (mm) & $1,120.26$ & $1,123.66$ & $1,140.51$ & $1,128.67$ \\
\hline 6 & DRO & 536.75 & 501.20 & 410.33 & 475.33 \\
\hline 7 & KAT & 0.25 & 0.23 & 0.19 & 0.22 \\
\hline \multirow[t]{2}{*}{8} & KRA & 98.63 & 74.93 & 67.43 & 74.46 \\
\hline & Penurunan $(\%)$ & 0.00 & & & \\
\hline
\end{tabular}

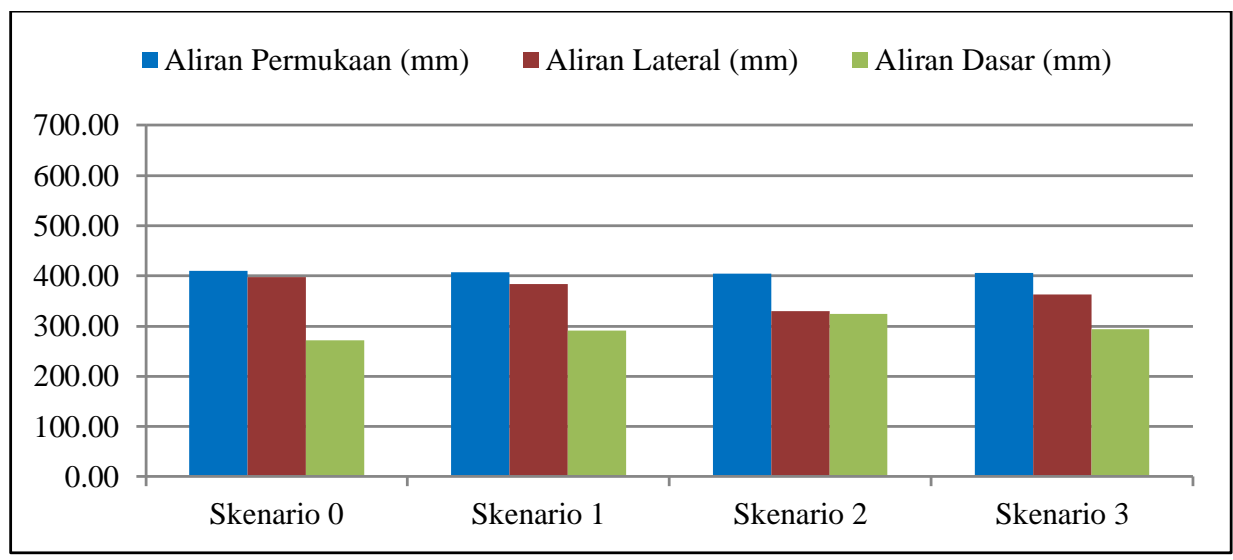

Gambar 4. Aliran permukaan, aliran lateral, dan aliran dasar tiap-tiap skenario 


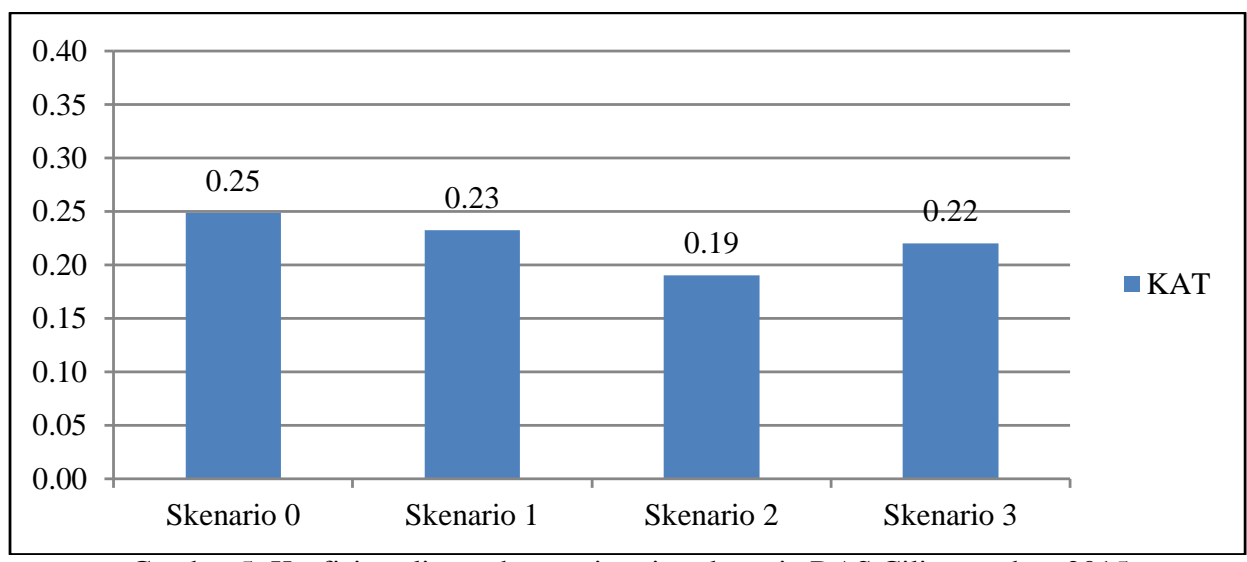

Gambar 5. Koefisien aliran tahunan tiap-tiap skenario DAS Ciliman tahun 2015

Tabel 6. Penerapan skenario 2 di DAS Ciliman

\begin{tabular}{clcr}
\hline No & Rekomendasi & Sub Basin & \multicolumn{1}{c}{ Luas (ha) } \\
\hline 1 & PB-HKB & 17 & 42.86 \\
2 & PB-LKB & 3,8 & 5.77 \\
3 & PB-TKB & $1-13,16-18,20,23$ & $11,593.10$ \\
4 & RL-THL & 18,23 & 496.48 \\
5 & RP-HHP & $15,17,22$ & 768.09 \\
6 & RP-THP & $9,12,14,20$ & $1,286.96$ \\
\hline & Jumlah & & $14,193.28$ \\
\hline
\end{tabular}

\section{SIMPULAN}

Model simulasi hidrologi SWAT menunjukkan bahwa seluruh skenario yang diterapkan dapat menurunkan respon hidrologi DAS Ciliman. Penerapan skenario teknik KTA dengan mengacu pada RTK RHL merupakan skenario terbaik karena mampu menekan aliran permukaan lebih besar dibandingkan skenario yang lain sehingga meningkatkan aliran dasar dari kondisi eksisting dan menurunkan koefisien aliran tahunan dari 0.25 (kondisi eksisting) menjadi 0.19.

\section{DAFTAR PUSTAKA}

Asdak, C. (2010). Hidologi dan Pengelolaan Daerah Aliran Sungai. Gadjah Mada University Press. Yogyakarta.

[BPS] Badan Pusat Statistik Kabupaten Pandeglang. 2015a. Lebak Dalam Angka. BPS Kabupaten Pandeglang. Banten

[BPS] Badan Pusat Statistik Kabupaten Pandeglang. 2015b. Pandeglang Dalam Angka: BPS Kabupaten Pandeglang. Banten
[Dinas PUPR] Dinas Pekerjaan Umum dan Perumahan Rakyat. 2015. Kajian Evaluasi Kinerja Penyelesaian Pengendalian Banjir DAS Ciliman. Laporan Akhir. Banten

[Dirjen RLPS] Direktorat Jenderal Rehabilitasi Lahan dan Perhutanan Sosial. 2014. Peraturan Direktur Jenderal Rehabilitasi Lahan dan Perhutanan Sosial Nomor: P. 61 /Menhut-II/2014 tentang Pedoman Monitoring dan Evaluasi Daerah Aliran Sungai. Jakarta.

Junaidy, E. 2013. Peranan penerapan agroforestry terhadap hasil air daerah aliran sungai (DAS) Cisadane. Jurnal Penelitian Agroforestry, 1(1):41-53

[Kemenhut] Kementrian Lingkungan Hidup dan Kehutanan. 2014. Peraturan Rehabilitasi Lahan dan Perhutanan Sosial Nomor: P.61/MenhutII/2014 tentang Pedoman Monitoring dan Evaluasi Daerah Aliran Sungai. Ditjen RLPSDephut. Jakarta.

Moriasi, D.N., J.G. Arnold, M.W. Van Liew, R.L. Bingner, R.D. Harmel and T.L. Veith. 2007. Model evaluation guidelines for systematic quantification of accuracy in watershed simulation. American Society of Agricultural and Biological Engineers, 50(3): 885-900.

[Pemprov Banten] Pemerintah Provinsi Banten. 2011. Peraturan Daerah No. 2 tentang Rencana Tata Ruang Wilayah Provinsi Banten Tahun 20102030. Pemerintah Provinsi Banten. Banten 